\title{
Camylofin in the management of prolonged labor: a review of evidence
}

\author{
N. Mayadeo' ${ }^{1}$ A. Gangadhar ${ }^{2 *}$, Srirupa $_{\operatorname{Das}^{3}}$
}

\author{
${ }^{1}$ Professor \& Unit Head, Department of Obstetrics and Gynaecology, KEM Hospital, Mumbai, Maharashtra, India \\ ${ }^{2}$ Senior Medical Advisor, Abbott Healthcare Pvt. Ltd., Mumbai, Maharashtra, India \\ ${ }^{3}$ Associate Director, Medical Affairs, Abbott Healthcare Pvt. Ltd., Mumbai, Maharashtra, India
}

Received: 09 January 2017

Accepted: 08 February 2017

\section{*Correspondence:}

Dr. A. Gangadhar,

E-mail: a.gangadhar@abbott.com

Copyright: () the author(s), publisher and licensee Medip Academy. This is an open-access article distributed under the terms of the Creative Commons Attribution Non-Commercial License, which permits unrestricted non-commercial use, distribution, and reproduction in any medium, provided the original work is properly cited.

\begin{abstract}
Prolonged labor can lead to increased maternal and neonatal morbidity and mortality. Hence, it warrants an early detection and appropriate clinical management. Active management of labor has shown to decrease the occurrence of prolonged labor. Administering antispasmodics during labor facilitates a faster and more effective dilatation of the cervix. Hence, antispasmodics can be used to decrease the incidence of prolonged labor. Camylofin, a potent antispasmodic, with a dual mode of action, has been used in the augmentation of labor for more than six decades. There is a growing body of evidence to support the efficacy and tolerability of Camylofin in the active management of labor. A review of published evidence suggests that Camylofin has superior efficacy in augmentation of labor on multiple counts like rate of cervical dilation, duration of active phase of first stage of labor and induction delivery interval, when compared to other spasmolytics like drotaverine, hyoscine and valethemate. It also has a benefit of a convenient single dose as compared to the other spasmolytics listed earlier. Camylofin has other advantages like a quick onset of action, prolonged action, no adverse effects on uterine contractility, no contraindication for use in uterine inertia cases and overall good tolerability for both mother and fetus. Given the superior efficacy and benefits that this drug exhibits, coupled with its excellent tolerability profile, Camylofin should be the first choice and may be preferred over other drugs for cervical dilatation and acceleration of active phase of labor.
\end{abstract}

Keywords: Active phase of labor, Camylofin, Cervical dilatation, Drotaverine, Hyoscine

\section{INTRODUCTION}

Labor is an important and memorable event in a woman's life. A painless and short labor is a cherished desire of every woman and the goal of obstetrics is a pregnancy that results in a healthy infant and minimally traumatized mother. ${ }^{1,2}$

There is a general consensus of opinion to classify labor lasting over 24 hours, as prolonged labor. ${ }^{2}$ Prolonged labor can lead to increased maternal and neonatal morbidity and mortality. This is due to increased risks of maternal exhaustion, postpartum hemorrhage, sepsis, fetal distress and asphyxia. Hence, this condition requires early detection and appropriate clinical management. These risks for complications of prolonged labor are much greater in poor resource settings. ${ }^{3}$

Active management of labor is commonly practiced in modern obstetrics. It has shown to decrease the occurrence of prolonged labor. Administering antispasmodics during labor facilitates a faster and more effective dilatation of the cervix. Hence, antispasmodics can be used to decrease the incidence of prolonged labor.

Camylofin is a drug that has been recommended for acceleration of labor for more than six decades. ${ }^{4}$ There is a growing body of evidence to support the efficacy and 
tolerability of Camylofin in the active management of labor. ${ }^{1,2,4}$ Since multiple antispasmodic agents are used for this purpose, there is a need to review the available evidence, to establish the current place of Camylofin in modern obstetrics.

\section{CAMYLOFIN IN THE MANAGEMENT OF PROLONGED LABOR}

Camylofin is an anti-spasmodic that is primarily used to relieve spasmodic and colicky pain of the abdominal viscera. The pharmacological properties of Camylofin as an anti-spasmodic, were first described by Brock in 1951. Ever since, the drug has traversed more than six decades of clinical use and continues to be a preferred antispasmodic for a variety of spasmodic pains of abdominal origin. Its dual musculotropic and neurotropic actions on smooth muscle relaxation make it one of the most potent antispasmodics. ${ }^{4-6}$

While Camylofin has recently garnered a renewed interest in the field of obstetrics, it must be noted that the role of Camylofin in augmentation of labor was demonstrated as early as 1951 by Losche. Following this, a slew of publications reported the efficacy of Camylofin in augmentation of Labor (Table 1).

Table 1: Clinical studies/publications on camylofin role in augmentation of labor.

\begin{tabular}{|l|l|}
\hline Investigator(s) & Year of publication \\
\hline Losche & 1951 \\
\hline Boldt W et al & 1952 \\
\hline Guseck E & 1952 \\
\hline Ascholter C & 1953 \\
\hline Drescher H ${ }^{12}$ & 1954 \\
\hline Jann R $^{13}$ & 1954 \\
\hline Etterich et al & 1959 \\
\hline Warke H et al & 2003 \\
\hline Sarbhjith K et al & 2013 \\
\hline Rajani U et al & 2015 \\
\hline Dayama S et al & 2016 \\
\hline
\end{tabular}

Noteworthy amongst these early publications, is the contribution of Etterich et al, who studied more than 9700 parturient women, where 2800 cases received antispasmodics and Asholter et al, who studied 300 primigravidae and 300 multigravidae for clinical effectiveness of these agents in augmentation of labor. These investigations suggested that Camylofin reduces the duration of the active phase of Labor in both primigravidas and multigravidas and this effect was found to be better than other spasmolytics used in these studies. ${ }^{4}$ Following this, the role and superiority of Camylofin in shortening the active phase of labor and cervical dilatation was demonstrated in multiple controlled trials, including placebo controlled trials and others comparing Camylofin with commonly used agents like drotaverine, hyoscine and valethemate..$^{1,2,7}$
The aim of this review is to evaluate and present the properties of Camylofin and its place in modern obstetrics for the augmentation of labor and cervical dilatation. Also presented, is an objective, evidence based, comparative account of the benefits of using Camylofin in such cases vis-à-vis other alternative management options

\section{CAMYLOFIN: MODE OF ACTION IN CERVICAL DILATATION}

Cervical dilatation is one of the important factors, which determines the duration of labor. It is the resultant of all the driving forces of uterine contraction acting against passive tissue resistance. ${ }^{1}$

Labor is associated with a fear-tension-pain syndrome, which results in increased tone of the muscles of the cervix. Excessive stimulation of the motor mechanism of the sympathetic nervous system increases the tone of the circular muscle fibers of the cervix. Resistance in these muscles produces pain by stimulating the sensory nerve endings. Thus, there is a painful spasm of the cervix, prolonging the labor. ${ }^{8}$

Camylofin primarily acts on the smooth muscles (intestine, ureter, cervix). It is a preferential cervical dilator, with no interference on the uterine contractions. Also, its pharmacological effect on glands, eyes, heart and circulation is minimal. ${ }^{4}$

Camylofin has a dual mode of action, i.e musculotropic and neurotropic actions for smooth muscle relaxation. Thus, on one hand, Camylofin has a direct papaverine like spasmolytic action on the smooth muscle, where it inhibits the enzyme phosphodiesterase, which in turn causes an increase in concentration of cyclic AMP and smooth muscle relaxation. On the other hand, it has a mild atropine like anticholinergic action also, making it one of the most potent antispasmodics. ${ }^{4,9}$

More importantly, Camylofin does not interfere with uterine contractility due to its phosphodiesterase IV isoenzyme selectivity. Owing to this preferential cervical dilating action, Camylofin can be recommended for use in accelerating the first stage of labor., ${ }^{4,8}$

\section{CAMYLOFIN: KEY ATTRIBUTES RELEVANT TO USE IN OBSTETRICS FOR THE AUGMENTATION OF LABOR}

An ideal antispasmodic for acceleration of cervical dilatation is general expected to have the features listed in Table 2. The table also lists how Camylofin performs on these attributes. Camylofin has a prompt as well a prolonged action, while not interfering with uterine contractions.

Camylofin shortens the duration of labor in primigravidas by $40 \%$ and multigravidas by $24 \%$. Also, Camylofin has 
no contraindications for use in cases with uterine inertia. $^{10}$

Table 2: Properties of an ideal antispasmodic for cervical dilatation and camylofin.

\begin{tabular}{|ll|}
\hline $\begin{array}{l}\text { Ideal } \\
\text { antispasmodic } \\
\text { for cervical } \\
\text { dilatation: key } \\
\text { attributes }\end{array}$ & Camylofin properties \\
\hline Prompt action & $\begin{array}{l}\text { At a dose of 50mg i.m, the onset of } \\
\text { action begins in 15-20 minutes }\end{array}$ \\
\hline $\begin{array}{l}\text { Long-lasting } \\
\text { action }\end{array}$ & $\begin{array}{l}\text { At a dose of 50mg i.m, the action } \\
\text { lasts for 4-5 hours. In clinical } \\
\text { studies, camylofin gives superior } \\
\text { results with just a single dose } \\
\text { compared to other molecules like } \\
\text { drotaverine, hyoscine and } \\
\text { valethemate, where multiple (2-3) } \\
\text { doses are required. }\end{array}$ \\
\hline $\begin{array}{l}\text { No adverse } \\
\text { effects on } \\
\text { uterine } \\
\text { contractility }\end{array}$ & $\begin{array}{l}\text { Clinical studies have suggested that } \\
\text { camylofin is a preferential cervical } \\
\text { dilator, with no effect on uterine } \\
\text { contractility. }\end{array}$ \\
\hline $\begin{array}{l}\text { Use in uterine } \\
\text { inertia }\end{array}$ & $\begin{array}{l}\text { No contraindication for use in } \\
\text { uterine inertia }\end{array}$ \\
\hline $\begin{array}{l}\text { Good } \\
\text { tolerability for } \\
\text { mother and } \\
\text { fetus }\end{array}$ & $\begin{array}{l}\text { Clinical studies have shown good } \\
\text { tolerability profile for both mother } \\
\text { and fetus. Adverse events like } \\
\text { maternal hypotension and fetal } \\
\text { tachycardia have not been reported } \\
\text { in studies with camylofin. }\end{array}$ \\
\hline
\end{tabular}

\section{EFFICACY AND TOLERABILITY OF CAMYLOFIN: REVIEW OF CLINICAL EVIDENCE}

Literature search on trials using camylofin in augmentation labor revealed 11 results. While some of these were non-comparative reports, in other studies, the efficacy and tolerability of Camylofin were compared with a placebo (2004, Warke et al), Drotaverine (2015, Rajani Uday et al), hyoscine (2016, Dayama et al) and a combination of hyoscine and valethamate (2013, Sarabhjit et al). The subsequent sections elaborately discuss these studies and their objectives and end outcomes.

\section{CAMYLOFIN: PLACEBO CONTROLLED TRIALS ${ }^{4}$}

Warke et al reported the results of a randomized placebo controlled trial enrolling 100 (average age 23 years) primigravidas to evaluate the efficacy and tolerability of Camylofin in active phase of labor. Camylofin $50 \mathrm{mg}$ I.M) and placebo were administered as a single dose.
Patients who received oxytocic drugs and artificial rupture of membranes were excluded from the study.

For the primary end point, which was the time from onset of active labor ( $3 \mathrm{~cm}$ cervical dilatation) to full cervical dilatation, Camylofin was significantly better than placebo. While the average time to full cervical dilatation was 3 hours 35 minutes in the Camylofin group and it was 5 hours 34 minutes in the placebo group, the difference attaining statistical significance $(\mathrm{p}<0.001)$. Thus, the average duration of active phase of first stage of labor was shortened by almost 2 hours in patients receiving Camylofin.

For the secondary outcome measure too, i.e. rate of cervical dilatation, camylofin was significantly better than placebo. The rate of cervical dilatation was $1.92 \mathrm{~cm} /$ hour in the camylofin group, which was almost double as compared to $1.18 \mathrm{~cm} / \mathrm{hr}$ in the control group $(p<0.001)$. Cervical dilatation was accelerated by 17 minutes/cm in patients receiving camylofin.

The investigators also reported a reduction of 2 hours, in the mean total duration of labor, (4 hours 42 minutes in the camylofin group versus 6 hours 31 minutes in the placebo group), which however, was attributable mainly to the effect on the first stage of labor. There was no effect on the uterine activity and neonatal outcomes were favorable. Hence, the investigators concluded that camylofin is a preferential cervical dilator and can be recommended for use in accelerating the first stage of labor.

\section{STUDIES OF CAMYLOFIN WITH ACTIVE COMPARATOR DRUGS}

\section{Camylofin versus drotaverin ${ }^{7}$}

Uday $R$ et al evaluated the comparative efficacy of camylofin vis a vis drotaverine in 126 primigravidae in active labor. The groups were randomized to receive either camylofin injection i.m or drotaverine hydrochloride i.v. to evaluate their effectiveness in cervical dilatation. Camylofin demonstrated a significantly superior effect on the cervical dilatation rate in the study. While the cervical dilatation rate was 1.78 $\mathrm{cm} /$ hour in the camylofin group and in the drotaverine group it was $1.61 / \mathrm{hr}(\mathrm{P}=0.002)$. This was despite that fact that $\sim 95 \%$ of camylofin group subjects delivering with only one injection, compared to the drotaverine group, where two injections were needed in majority (92\%) of the cases. $(\mathrm{P}<0.001)$. Also, the rate of cervical dilatation in camylofin group was more than drotaverine group irrespective of whether they received epidural $(\mathrm{p}=0.058)$ or $\operatorname{not}(\mathrm{p}=0.010)$.

Although, the mean duration of active phase of first stage of labor was also shorter in camylofin group (332.54 minutes) as compared to the drotaverine group (356.78 minutes), this difference did not attain statistical 
significance. However, even with a single dose of camylofin used in the study $(95 \%$ camylofin group patients) the mean 'induction-delivery' interval was significantly shorter in the camylofin group compared to the drotaverine group (207.96 minutes vs 228.38 minutes; $\mathrm{P}<0.05)$. In fact, a closer look at the results suggested that the 'induction-delivery' interval was less than 200 minutes in $46 \%$ subjects compared to only $31 \%$ subjects in the drotaverine group.

On basis of these findings, the investigators concluded that Camylofin has a superior efficacy than drotaverine in cervical dilatation and shortening of labor.

\section{Camylofin versus hyoscine ${ }^{1}$}

The superior efficacy of camylofin compared to hyoscine was demonstrated by Dayama et al in a randomized controlled trial involving 150 primigravida women. The subjects were randomized into three groups of 50 each, designated to be control group or camylofin group (i.m) or hyoscine group (i.v). In this study too, camylofin demonstrated a superior effect on the cervical dilatation compared to Hyoscine $(3.14 \mathrm{~cm} / \mathrm{hr}$ vs $2.78 \mathrm{~cm} / \mathrm{hr}$; $\mathrm{P}<0.001)$ and also when compared to control $(3.14 \mathrm{~cm} / \mathrm{hr}$ vs $1.97 \mathrm{~cm} / \mathrm{hr} ; \mathrm{P}<0.001)$. There was also statistically significant shortening of both $1^{\text {st }}$ and $3^{\text {rd }}$ stages of labor by camylofin compared to both control $(\mathrm{P}<0.001)$ and hyoscine groups $(\mathrm{P}<0.05)$.

\section{Camylofin versus hyoscine and valethamate combination therapy ${ }^{2,8}$}

Sarbhjit kaur et al studied the comparative efficacy of Camylofin administered as a single injection compared to a combination of Valethamate bromide plus hyoscine butyl bromide. The study enrolled 200 women, (primi and multigravidae) randomized to receive either camylofin $(n=100)$ or a combination of valethamate + hyoscine $(n=100)$. While the camylofin group received a single i.m dose, the valethamate + hyoscine group received 3 doses at hourly intervals. Despite this, the mean rate of cervical dilatation was higher $(3.33 \pm 1.03)$ $\mathrm{cm} / \mathrm{hr}$ in camylofin group than the valethamate + hyoscine group, $\quad(2.69 \pm 1.03 \mathrm{~cm} / \mathrm{hr}) \quad(\mathrm{P}<0.01)$. The duration of active phase of $1^{\text {st }}$ stage of labor was also significantly shorter in the camylofin group $(141.40 \pm 55.41$ minutes) compared to valethamate + hyoscine group (181.46 \pm 75.58 minutes). The difference between the two groups reached statistical significance $(\mathrm{p}<0.01)$. The mean duration of 'injection-delivery' interval was significantly shorter (172.05 \pm 60.82 minutes) in camylofin group as against (211.89 \pm 75.86 minutes) in valethamate + hyoscine group. This difference between the two groups was also statistically significant $(\mathrm{p}<0.01)$. Given these results, the investigators concluded that camylofin is a potent and effective drug to shorten the first stage of labor, with a positive impact on cervical dilatation, $1^{\text {st }}$ stage of active phase of labor and mean induction delivery interval. Its effect on shortening duration of labor is significantly better than valethamate and hyoscine given as a combination, although camylofin was given as a single dose and the combination was given as three doses.

\section{Camylofin versus valethamate ${ }^{11}$}

In a study comparing the efficacy and tolerability of camylofin and valethamate conducted by Kaur D et al, the investigators reported the superior efficacy and tolerability of camylofin. The study enrolled 200 women (100 in each treatment group) who were administered either one injection of camylofin or three injections (hourly) of valethamate. While the investigators concluded that the injection delivery interval was significantly shortened in the camylofin group, more specific findings in this regard were not available.

\section{Tolerability profile of camylofin $1,2,4,7,8$}

Camylofin primarily acts on smooth muscles (intestine, ureter, cervix), whereas its influence on glands, eyes, heart and circulation is of minimal clinical significance. It has very mild anticholinergic side effects like dryness of mouth, dilatation of pupils and palpitations. It has a wide margin of safety. The ratio of the effective therapeutic dose to the toxicity dose in animal studies varies from $1: 40$ to $1: 150.5$.

In all the studies reviewed here, camylofin was reported to have minimal side effects and favorable neonatal outcomes. The drug demonstrated a good tolerability profile in both primigravida and multigravida subjects. Also, camylofin does not interfere with normal placental separation or affect the blood loss in the third stage of labor. Mild adverse events like nausea, vomiting, maternal tachycardia and dryness of mouth were reported in therapy with camylofin. However, noteworthy here, is the fact that there are no reports of adverse events like maternal hypotension and fetal tachycardia in the studies reviewed. However, in the same studies, maternal hypotension and fetal tachycardia have been reported with the use of other agents.

\section{Summary of benefits of camylofin vis-a-vis other agents}

Review of available literature suggests several features and benefits that favor the use of camylofin injection in acceleration of labor. Camylofin has a prompt onset and a long duration of action, coupled with superior efficacy compared to other agents like drotaverine, hyoscine and valethamate. The results from various studies consistently demonstrate its efficacy in acceleration of labor in young women, both primi-gravida and multi-gravida (parity has an important effect on duration of labor). Camylofin also has the convenience of a single dose and cost effectiveness, unlike other drugs needed in multiple doses. The effect of camylofin on cervical dilatation is independent of epidural analgesia. Overall, camylofin has demonstrated a good tolerability profile, with no reports 
of maternal hypotension and favorable neonatal outcomes in the clinical studies. Lastly, the drug has a history of sixty years of clinical use and more importantly has clinical data on efficacy and tolerability in Indian patients.

\section{CONCLUSION}

It is evident from the review of the available data that camylofin is a potent, superior and reliable alternative when compared to other spasmolytics like drotaverine, hyoscine and valethemate in the acceleration of labor. Given the superior efficacy and benefits that this drug exhibits, coupled with its excellent tolerability profile in these patients, camylofin should be the first choice and may be preferred over other drugs for cervical dilatation and acceleration of active phase of labor. Further, large scale, more robustly designed studies are needed to supplement the existing evidence and clearly establish the comparative efficacy of agents that are used for cervical dilation and acceleration of labor.

\section{Funding: No funding sources}

Conflict of interest: None declared

Ethical approval: Not required

\section{REFERENCES}

1. Dayama SS, Patil SS, Sambarey PW. A randomised controlled study of intramuscular camylofin dihydrochloride vs intravenous hyoscine butylbromide in augmentation of labour. Global J Med Res: Gynecol Obstet. 2016;16(1):1-6.

2. Kaur S, Bajwa SK, Kaur P, Bhupal S. To compare the effect of camylofin dihydrochloride (anafortin) with combination of valethamate bromide (epidosin) and hyoscine butyl-n-bormide (buscopan) on cervical dilation. J Clin Diagn Res. 2013;7(9):1897-9.

3. Aziz M. Comparative study of tramadol hydrochloride and drotavarine hydrochloride on cervical dilatation in active labour. Int $\mathrm{J}$ Sci Tech Res. 2014;3(4):338-47.

4. Warke HS, Chauhan AR, Raut VS, Ingle KM, Efficacy of camylofin dihydrochloride in acceleration of labour. A randomised double blind trial. Bombay Hospital J. 2003;1.45(3)420-3.

5. Gabhane M, Braganza L, Das S, et al. Recommendation patterns by various practitioners in the treatment of colicky abdominal pain in India. IJCP. 2016;28(10):933-7.

6. Gabhane M, Braganza L. Preference trends for antispasmodics among Indian healthcare professionals. Results of a cross sectional survey. Indian Pract. 2015;28(10):32-7.

7. Rajani U, Binu P. A Randomized Comparative Study of Intramuscular Camylofin Dihydrochloride and Intravenous Drotaverine Hydrochloride on Cervical Dilatation in Labor. Indian $\mathrm{J}$ Clinical Practice. 2015;26(6):558-63.

8. Kaur S, Kaur P, Bajwa SK, Kumari S, Mohi MK. To evaluate the incidence of side effects of camylofindihydrochloride with combination of valethemate bromide (epidosin) and hyoscine- $\mathrm{N}$ butyl bromide (Buscopan), on mother and to look for neonatal outcome. J Med Health Sci. 2013;1.2(4):337.

9. E B, Mutschler E, "Spasmolytics. In: Ullmann's Encyclopedia of Industrial Chemistry.Wiley, 2012;34:1-15.

10. Desai SN, Desai SV. Optimizing labour and delivery - use of the indigenous protocol. In: Selected topics in obstetrics and gynaecology-1 for postgraduates and practitioners. B I Publications; 2005:59-60.

11. Kaur D, Kaur A. "Anafortan" an old drug with its newer use in acceleration of labour [abstract]. 49th All India Congress of Obstetrics and Gynaecology; 2006 January 6-9; Cochin, Kerala State, India. 2006:59.

12. Drescher H. Experience with the spasmolyticum avacan in obstetrics]. Munch Med Wochenschr. 1954;96(40):11645.

13. Jann R. Experience with the spasmolytic avacan in obstetrics. Ther Umsch. 1954;11(4):802.

Cite this article as: Mayadeo N, Gangadhar A, Das $\mathrm{S}$. Camylofin in the management of prolonged labor: a review of evidence. Int $\mathrm{J}$ Reprod Contracept Obstet Gynecol 2017;6:776-80. 